ХРОНИКА

DOI: $10.17805 /$ trudy.2015.5.9

\title{
МЕЖДУНАРОДНАЯ МЕЖДИСЦИПЛИНАРНАЯ НАУЧНО-ПРАКТИЧЕСКАЯ КОНФЕРЕНЦИЯ «РОЛЬ ФАКТА И ВООБРАЖЕНИЯ В КОНСТРУИРОВАНИИ ХУДОЖЕСТВЕННЫХ И ВИРТУАЛЬНЫХ МИРОВ ШЕКСПИРОВСКОЙ АНГЛИИ»*
}

\author{
Е. А. Шустова \\ (Московский гуманитарный университет)
}

Аннотация: В статье представлен анализ данных экспресс-опроса первокурсников МосГУ, проведенного в феврале 2015 г., в котором косвенно проявились их ценностные ориентации и определенные мировоззренческие позиции.

Ключевые слова: обзор; конференция; шекспироведение; Московский гуманитарный университет; шекспиросфера

INTERNATIONAL INTERDISCIPLINARY CONFERENCE "FACT AND IMAGINATION IN CONSTRUCTING ARTISTIC AND VIRTUAL WORLDS OF SHAKESPEARE'S ENGLAND”

\author{
E. A. Shustova \\ (Moscow University for the Humanities)
}

Abstract: The article reviews the international interdisciplinary conference "Fact and imagination in constructing artistic and virtual worlds of Shakespeare's England" which was held on June 25-26, 2015 at Moscow University for the Humanities.

Keywords: review article; conference; Shakespeare studies; Moscow University for the Humanities; Shakespearean sphere

25-26 июня 2015 г. в Москве проходила Международная междисциплинарная научно-практическая конференция «Роль факта и воображения в конструировании художественных и виртуальных миров шекспировской Англии». Конференция была организована при финансовой поддержке Российского гуманитарного научного фонда (РГНФ), проект «Виртуальная шекспиросфера: трансформации шекспировского мифа в

\footnotetext{
" Обзор подготовлен в рамках проекта «Виртуальная шекспиросфера: трансформации шекспировского мифа в современной культуре», поддержанного грантом РГНФ (№ 14-03-00552a).

This review article was written as part of the "Virtual Shakesphearean Sphere: Transformations of Shakespearean Myth in Modern Culture" (supported by the Russian Foundation for the Humanities, Grant No. 14-03-00552a).
} 
современной культуре», № 14-03-00552(а). Организаторами конференции выступили Институт фундаментальных и прикладных исследований Московского гуманитарного университета, Шекспировская комиссия при Научном совете «История мировой культуры» Российской академии наук, Государственный институт искусствознания, Российский университет театрального искусства - ГИТИС, Международная академия наук (IAS).

В оргкомитет вошли российские и зарубежные ученые: кандидат филологических наук, доцент кафедры философии, культурологии и политологии МосГУ Инна Ивановна Лисович (председатель оргкомитета); доктор искусствоведения, профессор, заведующий сектором современного искусства Запада Государственного института искусствознания, заведующий кафедрой истории зарубежного театра Российского университета театрального искусства - ГИТИС, заслуженный деятель науки РФ, председатель Шекспировской комиссии при Научном совете «История мировой культуры» РАН Алексей Вадимович Бартошевич; доктор философии (PhD), профессор славистики Университета Тулейна (Новый Opлеан, США) Уильям Крафт Брумфилд; доктор философских наук, професcop, директор Института фундаментальных и прикладных исследований МосГУ, заслуженный деятель науки РФ, вице-президент Русского отделения Международной академии наук (IAS, Австрия), академик Международной академии наук педагогического образования Валерий Андреевич Луков; доктор философии (PhD), кандидат филологических наук, директор Центра теории и истории культуры ИФПИ МосГУ, ученый секретарь Шекспировской комиссии РАН, академик Международной академии наук (IAS, Австрия) Николай Владимирович Захаров; кандидат филологических наук, заместитель директора Центра теории и истории культуры ИФПИ МосГУ, член-корреспондент Международной академии наук (IAS, Австрия) Владимир Сергеевич Макаров; кандидат философских наук, заместитель директора Центра теории и истории культуры ИФПИ МосГУ, член-корреспондент Международной академии наук (IAS, Австрия) Борис Николаевич Гайдин; доктор филологических наук, профессор, заведующий кафедрой перевода и переводоведения Пензенского государственного технологического университета Дмитрий Николаевич Жаткин.

Для докладов и обсуждения были предложены следующие темы:

• воображаемое как предмет рефлексии в культуре раннего Нового времени;

•шекспиросфера как воображаемый конструкт;

- факт и воображение в стратфордианских и антистратфордианских теориях;

- факт и воображение в шекспировской версии истории Англии: прошлого (сходящая со сцены средневековая Англия), настоящего (Англия 
Тюдоров и Стюартов с ее политическими и культурными амбициями) и будущего (Англия как «Новая Троя» на Темзе, будущая мировая империя);

• воображение писателей, ученых, философов, теологов, читателей и зрителей шекспировской Англии;

- воображение писателей, ученых, философов, теологов, художников, режиссеров, читателей и зрителей о Шекспире, его пьесах, культуре и истории шекспировской Англии;

• визуальный Шекспир и шекспировское как воображаемое в театре, живописи, кино, фотографии, комиксах, рекламе;

-Шекспир в воображении иных культур.

Конференция носила междисциплинарный формат, к участию были приглашены исследователи в области литературоведения, культурологии, истории, социологии, политологии, искусствоведения, культурной антропологии, социологии культуры, истории культуры, визуальных исследований и других смежных направлений. В пяти секционных заседаниях приняли участие 25 ученых из Москвы, Вильнюса (Литва), Калуги, Кирова, Нового Орлеана (США), Пензы и Ростова-на-Дону.

Секции: «Воображение как объект теоретической рефлексии» (модератор - В. С. Макаров); «Воображаемое в текстах шекспировской эпохи» (модератор - Б. Н. Гайдин); «Воображаемый Шекспир: от эпохи просвещения до эпохи модернизма» (модератор - И. И. Лисович); «Шекспир в воображении современной культуры» (модератор - Н. В. Захаров).

25 июня 2015 г. участников конференции приветствовал доктор философских наук, профессор, директор ИФПИ МосГУ В. А. Луков. Он рассказал о традиции шекспировских исследований в МосГУ и проекте «Виртуальная шекспиросфера: трансформации шекспировского мифа в современной культуре», в рамках которого была организована данная конференция. Свое выступление Вал. А. Луков продолжил докладом «Шекспиросфера как социокультурный конструкт: факт \& воображение», где обозначил проблему соотношения этих концептов, которые проявляют себя в современной культуре от интерпретаций произведений и биографии Шекспира до объектов туристической и сувенирной индустрии. Он подчеркнул, что изучение именно воображаемого о Шекспире является основой для междисциплинарных исследований.

Секция «Воображение как объект теоретической рефлексии» была посвящена анализу понятия «воображение» в европейской культуре раннего Нового времени.

Надежда Ивановна Прозорова (КГУ им. К. Э. Циолковского) в докладе «“...Из вещества того же, что наши сны”: парадоксы воображения в зеркале театра» пришла к наблюдению, что театр стал для современной 
философско-эстетической мысли наглядной моделью творческого сознания, поскольку он изображает «неизобразимое», материализуя на сцене «фантомы» творческого воображения художника-драматурга. У истоков подобного явления - театр Шекспира с характерными для него приемами разрушения сценической иллюзии и вовлечения зрителя в театральную игру, которая несет в себе эстетическую саморефлексию, направленную на постижение природы театра. В каждом театральном представлении есть общее свойство спонтанно раздваиваться на вымысел и рефлексию по поводу этого вымысла, и каждый театр оказывается в большей или меньшей степени метатеатром. Елена Сергеевна Гордеева (независимый исследователь) рассмотрела «Понятия “imagination”, “conceit” и “invention” как объекты рефлексии в шекспировской Англии» на примере Дж. Бруно, который, как она полагает, стал воображаемым прототипом шекспировского «Гамлета». Бруно полагал, что при помощи магического воображения можно общаться с даймонами, и в сцене с призраком можно найти отражение этого представления. Инна Ивановна Лисович (MосГУ) в докладе «Воображение между наукой и искусством в шекспировской Англии» на основании высказываний Ф. Сидни, Дж. Бруно, У. Гилберта, Ф. Бэкона, Р. Бернса, Р. Декарта и др. представила воображение как конструктивное начало разума, которое в эпоху размывания иерархических границ между когнитивными способностями души, свободными искусствами и ступенями Великой Цепи Бытия в аристотелианской Вселенной способно проникнуть и в метафизические сферы, создавая идеальные образы. Но ученые Лондонского королевского общества давали поэзии понять, что познавать мир и подтверждать гипотезы нужно методом эксперимента и регистрировать знание при помощи точных характеристик; что воображение, «остроумие» (wit) и метонимия не являются аргументом и не свидетельствуют об истине; что ученый не обязан быть поэтом, но поэт должен следовать за ученым, если у него есть желание воспевать тайны Вселенной. Александр Викторович Марков (РГГУ, МГУ) представил доклад «Раннеклассицистская теория примера как изобретение воображаемого», в котором на материале поэтик (от Скалигера до Воссиуса) рассмотрел историю словоупотребления близких понятий “exemplum”, "specimen” и “instar”, повлиявших на литературную рефлексию и статус отдельных жанров. Когда поэтика воспринимается как создание с помощью воображения идеальных произведений (а не решение риторических задач), "ехеmplum” становится “примером", “specimen” - обоснованием шедевров, видимых со стороны автора, а “instar” виден и внешнему наблюдателю (он и переходит в естественнонаучный контекст).

Секцию завершила презентация книг.

Марков А. В. Одиссеас Элитис. - СПб. : Алетейя, 2014. - 288 с. 
Александр Викторович рассказал о том, что это - первая книга на русском языке, посвященная Одиссеасу Элитису (1911-1996) лауреату Нобелевской премии. Работа над книгой началась в 90-е гг. Элитис поэт «гимнического» склада, наследующий одновременно классической античной образности, церковной византийской поэзии и европейскому высокому модернизму от Пиндара до Матисса. В поэзии Элитиса доминирует тема рождения: рождение как вхождение в мир; рождение мысли, себя, любви и т. д. Он пытается выстроить новую оптику: соединить слово, видимое и воображаемое в Логосе.

Марков А. В. Культурология : учебник для вузов. Ростов-на-Дону : Феникс, 2015.

Автор выразил надежду, что учебник увидит свет осенью этого года. Поводом для написания учебника стала полемическая цель: вводя любое культурологическое понятие, необходимо проследить его историю, что и было реализовано в издании.

На секции «Воображаемое в текстах шекспировской эпохи» были представлены доклады, посвященные частным примерам репрезентации воображения.

Виктория Александровна Мусвик (ЕГУ, Вильнюс, Литва) выступила с докладом «Покрывало Тиманта и “зодиак воображения”: факт, визуальное и воображение у Филипа Сидни», где отметила, что Сидни увлекался историческими штудиями, но одновременно в «Защите поэзии» ставил поэта выше историка. Теме не менее, это - кажущийся парадокс, поскольку все зависит от способа разграничения вымысла и факта, типического и жизнеподобного, что было продемонстрировано на примере «Аркадии», где воспроизведены античная, старая немодная, столетней давности (средневековая) и современная елизаветинская манеры одеваться. Это смешение связано с рождением чувства исторического прошлого, которое начали разграничивать уже гуманисты. Но наряду с историческим материалом Сидни вводит воображаемый: рядом с историческими фигурами действуют гомеровские персонажи, фигурирует условно-воображаемая одежда (покрывало Тиманта), сырые факты истории гармонично вписываются в воображаемое. Александр Николаевич Баранов (ГМИИ им. А. С. Пушкина) в докладе «Шекспир о воображении: воображение как тема шекспировской драматургии» развернул тезис, что Шекспир сознательно работал с воображением. Он напоминал зрителям, что спектакль есть вымысел, игра, плод работы фантазии - драматурга, актеров и зрителей. В пьесах Шекспира встречаются эпизоды свободной игры воображения как самоцели для персонажей. Более того, герои часто зависимы от воображаемого, своего или чужого, включая бессознательную работу воображения (сон и бред). Жизнь как сон или фантазия смыкается с метафорой жизни как театра. Мария Витальевна Елиферова (РГГУ) в докладе «Время в вооб- 
ражении елизаветинцев: кто именно выходил на сцену в “Зимней сказке”?» выдвинула тезис, что Время в прологе пьесы отсылало воображение зрителей к ренессансной традиции иконического персонифицированного образа крылатого старика-Сатурна с песочными часами. Визуальный материал XVI-XVII вв. демонстрирует разнообразие интерпретаций Сатурна: он ассоциируется с циклом обновления (плодородием и золотым веком, а так же со смертью, временем и меланхолией, кроме того - он защитник искусств и наук). Возможно, в образе Времени на сцену выходил сам пожилой Шекспир. Мария Сергеевна Неклюдова (РГГУ) представила доклад «Между фактом и фантазией: область (не)вероятного во французской словесности XVII века», где рассмотрела проблему воображаемой реконструкции прошлого, которая занимала французских историков и писателей XVII столетия, что к концу века вылилось в моральное противостояние «истории» и «романа» (вымысла, фантазии). Позиция аббата Лангле-Дюфренуа показывала амбивалентность области «вероятного», с которой соприкасались историки и которую в XVII веке начинают эксплуатировать романисты. Роман рассматривается при помощи тех же категорий, что и историческое повествование, и это усиливало путаницу между «фактами» и «фантазией». Хотя история уже мыслилась обладающей четкой фактографической структурой, но вымысел проникал в описание человеческой природы и мотивов поступков, что делало возможным подключение к истории романного повествования и создание иллюзии правдоподобия (романы мадам де ля Форс, де Скюдери, де Лафайет). В итоге «историю» тоже подозревают в вымысле, что приводит к скептическому отношению к ней и даже отрицанию.

По завершении секции участники конференции совершили экскурсионную прогулку по музею-усадьбе «Кусково».

26 июня 2015 г. Секция «Воображаемый Шекспир: от эпохи просвещения до эпохи модернизма» была посвящена рецепции шекспировского творчества.

Арсений Игоревич Кузьмичев (ИНИОН РАН) в докладе «Шекспировская галерея Бойделла и переход от визуальной эстетики Просвещения к романтической эстетике воображения» рассказал о Шекспировской галерее Джона Бойделла (1720-1804), где были собраны картины и гравюры лучших художников Англии (Джошуа Рейнольдса, Генри Фузели, Ричарда Уэстфолла и др.). Дж. Бойделл полагал, что художники должны «забыть то, что они видели из Шекспира в театре», так как театр не историчен, в своих произвольных фантазиях он искажает первоначальные образы, использует адаптации пьес. Это послужило причиной разрыва романтиков с предшествующей традицией восприятия Шекспира. Николай Владимирович Захаров (Шекспировская комиссия РАН, МосГУ) представил 
доклад «Воображение драматургии у Шекспира и Пушкина», где провел сравнительный анализ принципов сценичности двух поэтов. Если пьесы У. Шекспира предназначены для сценического воплощения и на протяжении более 400 веков с успехом ставились на мировых театральных подмостках (иногда в адаптированном виде), то пушкинские драмы с трудом поддаются театрализации, успешны только усеченные оперные и киноинтерпретации, что позволяет сделать предположение, что они в большей степени, чем шекспировские тексты, апеллировали к воображению читателя / зрителя и выходили за рамки тогдашних сценических возможностей. Дмитрий Николаевич Жаткин и Татьяна Сергеевна Круглова (ПензГТУ) в докладе «Шекспир в воображении Марины Цветаевой» сделали попытку систематизации интерпретаций М. Цветаевой образов У. Шекспира. Многие суждения поэтессы о Шекспире были обусловлены событиями современной ей театральной жизни, стремлением увидеть различия между поэтом и актером, размышлениями о голосе актера и др. Например, в цикле «Гамлет» воображение Цветаевой трансформировало образы Гамлета, Офелии и Королевы. Можно говорить о «шекспировской натуре» М. Цветаевой и «шекспировских бурях» в ее душе. Таисия Сергеевна Паниотова (ЮФУ) в докладе «Воображение как творение новых смыслов: герои шекспировской “Бури” в латиноамериканском культурном контексте» анализировала факт необычайной популярности «Бури» у латиноамериканских интеллектуалов, которые переосмыслили ее образы в контексте воображаемой латиноамериканской идентичности. Аргентинец Поль Гроссак говорит о «калибанском духе янки». Для уругвайца Э. Х. Родо Ариэль символизирует духовность и возвышенность Латинской Америки, а Калибан - меркантилизм, утилитаризм и агрессивность США. Для А. Понсе Просперо - это просвещенный тиран эпохи Возрождения; Калибан - угнетенный и страдающий народ, Ариэль - символ интеллектуала. Тогда как кубинец Р. Ф. Ретамар провозгласил: «Наш символ не Ариэль, а Калибан»: Просперо вторгся на остров, где жил метис Калибан, обратил в рабство, навязал язык, на котором последний теперь проклинает завоевателя.

Секция «Шекспир в воображении современной культуры» представила творчество драматурга в формах современной культуры.

Фаина Ионтелевна Гаврилина (Фаина Гримберг; Союз писателей Москвы) представила доклад «Шекспир в советском кино: от текста к визуальному воображаемому», где предположила, что режиссерам интересны лишь свои воображаемые преставления и фантазии о Шекспире, а его тексты, личность и эпоха являются материалом. Рациональность этого видения связана с тем, что приближение к тексту, драматургу и елизаветинскому времени может напугать современного человека. K таким экранизациям можно отнести фильмы «Двенадцатая ночь» Я. Фрида и 
«Отелло» С. Юткевича. Они близки театру Шекспира тем, что он будил воображение зрителей и одновременно развлекал их. Советские зрители также нуждались в праздничном карнавальном эскапизме. По мнению докладчика, Г. Козинцев отказался от праздничности, ярких красок и стремился воссоздать великое в своих киноверсиях «Гамлета» и «Короля Лира», но получились всего лишь добротные фильмы. Воображаемому Шекспиру режиссера мешал реальный негуманный и неполиткорректный Шекспир (моралист, англиканец, конформист и т. д.). Борис Николаевич Гайдин (МосГУ) в докладе «Воображая Шекспира: вербальное и визуальное в кино и на телевидении» рассмотрел возрастающее влияние голливудского популярного кинематографа на современное российское кино на примере фильма Ю. Кары «Гамлет XXI век». Слоган фильма - «Шекспировская готика оживает» - реализован в антураже готической субкультуры на фоне современных крымских пейзажей и путем включения в сюжет нарезки из классических русских переводов Шекспира, «приправленной» злободневными аллюзиями. Но отсутствие собственного воображения, купирование шекспировской многозначности и копирование готовых решений не ведет к развитию кино и искажает текст оригинала. «Ералаш» дважды обратился к «Отелло», в обоих случаях комический эффект основан на смешении шекспировского пафоса с реалиями школьного быта, современной повседневной лексикой и рэповой импровизацией. Современные режиссеры делают акцент не на тексте Шекспира, а шаблонном визуальном сопровождении. Владимир Сергеевич Макаров (МосГУ) в докладе «Воображаемый шекспировский Лондон: цифровые реконструкции и литературный текст» отметил, что в современных цифровых реконструкциях Лондона XVI-XVII веков очень большую роль играет литературный текст. Так, в американском проекте «Виртуальный крест собора св. Павла» коллаж звуков и набор ракурсов объединяются не столько вокруг самого собора, сколько вокруг «Креста Павла» - крытого возвышения, на котором стоит проповедник, произносящий конкретный текст - проповедь, которую на этом месте произнес Джон Донн. Еще более показательный пример - «Карта Лондона раннего Нового времени», проект канадского Университета Виктории. В словарных статьях, посвященных улицам и городским объектам, литературный текст в виде прямых цитат из Джонсона, Деккера, Шекспира занимает настолько важное место, что перед нами, в сущности, воссоздание литературного Лондона, города, каким его запомнили посетители театров и драматурги. Разумеется, такая работа оказалась возможна только на основе длительных и подробно описанных археологических и архивных исследований, но сам факт важности литературного текста для цифровой реконструкции показывает, что последняя объединяет в себе элементы науки и искусства. Екатерина Николаевна Шапинская (ИКПН им. Д. С. Лихачева) представила доклад 
«“Буря” У. Шекспира и опера Т. Адеса “Буря”: шекспировская фантазия и музыкальное воображение». Т. Адес в своей оперной интерпретации сделал акцент на смешение сна и реальности, что отражено в оперных ариях, музыке и фантазийных костюмах. Используется прием театра в театре, подчеркивающий строки «Мы созданы из вещества того же, // Что наши сны. И сном окружена // Вся наша маленькая жизнь». Волшебство и воображение мага Просперо бессильны перед реальностью и любовью, и он отказывается от власти. Фантазийный мир острова - это аллегория всего человеческого мира с его страстями. Опера ставит ряд вопросов: разграничение реального и воображаемого, чувственного и трансцендентного. Виталий Романович Поплавский (театр-студия «Горизонт» МГДУ, МосГУ) в сообщении «Театральный сезон 2014-2015: опыт постановки “Гамлета” У. Шекспира (воображаемый и визуальный образы спектакля)» рассказал о работе режиссерского воображения в своей постановке пьесы «Гамлет» в собственном же переводе. Предметом анализа стало пересечение драматического текста, визуального образа и смысла спектакля в условиях минимального использования театральной бутафории и бедности средств выражения. Постановка реализовалась на основании принципа исключения (в том числе и зрелищности), что в конечном итоге стимулировало условность происходящего на сцене и запустило воображение не только режиссера, актеров, но и зрителей.

В заключение конференции состоялась презентация книги: Лисович И. И. Скальпель разума и крылья воображения: Научные дискурсы в английской культуре раннего Нового времени. - М. : Изд. дом Высшей школы экономики, 2015. - 440 с.

Инна Ивановна отметила, что когда идет речь об этой книге, все обращают внимание на подзаголовок, и никто не задается вопросом о поэтическом названии. Действительно, в тексте достаточно часто в разных местах встречается слово «воображение». Исследование посвящено ситуации, когда обычные люди были вынуждены встраивать свое бытие, сознание, мышление и воображение в изменяющуюся картину мира. Примером восприятия научных концепций и открытий может послужить остроумие (wit) и поэтическая метафора-кончетти, которая разворачивала научные идеи и восполняла недостаток индукции, мгновенно восходя от частного к общему, поскольку воображение поэта (Сидни, Шекспира, Донна и др.) не было ограничено, тогда как ученый был скован экспериментальными и логическими процедурами доказательства. Аристотель, Р. Бертон и Ф. Бэкон рекомендовали критически относиться к плодам воображения и контролировать его с помощью разума. На фоне противостояния неоплатоников и аристотеликов наблюдается разрушение дискурсивных границ между свободными искусствами, что в конечном итоге завершилось формированием новой науки и единого математического 
языка и терминологического аппарата.

По результатам конференции планируется издание одноименного сборника.

Шустова Елена Алексеевна - кандидат экономических наук, начальник Управления аспиранты, докторантуры и научной работы Московского гуманитарного университета. Адрес: 111395, Россия, г. Москва, ул. Юности, д. 5, корп. 6. Тел.: +7 (499) 374-75-90. Эл. адрес: shustova13@ yandex.ru

Shustova Elena Alekseyevna, Candidate of Economics, Head of the Office of Postgraduate and Doctoral Studies and Research, Moscow University for the Humanities. Postal address: 5 Bldg.6 Yunosti St., 111395 Moscow, Russian Federation. Tel.+7 (499) 374-75-90. Email: shustova13@yandex.ru 